DOI: https://doi.org/10.32653/CH173581-605

Sharafetdin A. Magaramov

$\mathrm{PhD}$ in History, Senior Researcher

Institute of History, Archeology and Ethnography

Dagestan Federal Research Center of RAS, Makhachkala, Russia

sharafutdin@list.ru

\title{
HISTORIOGRAPHY OF THE PERSIAN CAMPAIGN OF PETER THE GREAT 1722-1723 AND ITS RESULTS (TO THE 3OOTH ANNIVERSARY)
}

\begin{abstract}
The article is devoted to the historiographic understanding of the problem of the Persian campaign of 1722-1723. Peter the Great and the stay of the Russian imperial army in the southwestern Caspian region in the first third of the 18th century. The work examines the process of the formation and evolution of the approaches of historians and historical thought on the problem for almost three centuries. Historiographic comprehension of the problem will make it possible to trace the dynamics of historical thought in the history of the Persian campaign, identify the most poorly developed aspects, show innovative assessments of authors of different historical eras, and update new plots. The relevance of this study is also due to the absence of a historiographical sketch even in the genre of an article on the history of the Persian campaign of Peter I. The pre-revolutionary historiography's practice of studying the Persian campaign in the context of studying the wars of conquest of the Russian Empire in the Caucasus is analyzed. The works of military and civil historians of this period served a political purpose - to substantiate the advancement and establishment of the empire in the Caucasus region. The main attention was paid to the militarypolitical side of the campaign, its foreign policy background. At the same time, the first special historical studies on the history of the campaign appeared, which are valuable historiographic sources. Many of them were written on the basis of handwritten documents from the personal archive of Peter I, some of which were later lost or became difficult to access. In the Soviet era, the study of various aspects of the campaign, associated with its prerequisites and reasons, the economic and economic development of the region, was significantly expanding, new documentary data were introduced into scientific circulation. Soviet historians adhered to the concept of the objectively progressive meaning of the annexation of the Caspian regions to the Russian Empire, regardless of whatever goals tsarism pursued. The Persian campaign of Peter I was assessed as the protection of the Caucasian peoples from the tyranny of Iran and Turkey. In the last two or three decades, in the study of the problem of the military-political campaign of 1722-1723. empire, there were significant successes associated with the development of new plots, using modern historical approaches and the introduction into scientific circulation of a colossal fund of archival documents and narrative sources. At the same time, in the 1990s, there are attempts to revise the "Persian campaign", to replace it with a new name - "Caspian campaign", which has not been established outside the limits of regional Caucasian studies. At the present stage, researchers deepen and expand the existing scientific understanding of this problem by applying such scientific approaches as the history of everyday life, military-historical anthropology. In modern domestic historiography, there has been a tendency to study the historical memory of Dagestan society about the image of Peter I, and to study the problem from the standpoint of the Russian-Persian-Ottoman borderland (frontier), which acted not only as a zone of conflict, resistance, but also the interaction of border communities and their elites.

Keywords: Peter the Great; Persian campaign of the 1722-1723; Nizovoy Corps; Western Caspian region; historiography.
\end{abstract}

(C) Sh.A. Magaramov, 2021

(C) Daghestan Federal Research Centre of RAS, 2021 
Шарафетдин Арифович Магарамов

к.и.н., старший научный сотрудник

Институт истории, археологии и этнографии

Дагестанский федеральный исследовательский центр РАН, Махачкала, Россия sharafutdin@list.ru

\section{ИСТОРИОГРАФИЯ ПЕРСИДСКОГО ПОХОДА ПЕТРА ВЕЛИКОГО 1722-1723 ГГ. И ЕГО ПОСЛЕДСТВИЙ (К ЗОО-ЛЕТИЮ ПОХОДА)}

Аннотация. Статья посвящена историографическому осмыслению проблемы Персидского похода 1722-1723 гг. Петра Великого и пребывания российской императорской армии в юго-западном Прикаспии в первой трети XVIII в. Историографическое осмысление проблемы даст возможность проследить динамику исторической мысли по истории Персидского похода на протяжении почти трех столетий, выявить наиболее слабо разработанные аспекты, показать новаторские оценки авторов разных исторических эпох, актуализировать новые сюжеты. Актуальность настоящего исследования также вызвана отсутствием историографического очерка даже в жанре статьи по истории Персидского похода Петра I. Проанализирована господствовавшая в дореволюционной историографии практика изучения Персидского похода в контексте изучения завоевательных войн Российской империи на Кавказе. Труды военных и гражданских историков этого периода служили политической цели - обоснованию продвижения и утверждения империи на Кавказском регионе. Главное внимание уделялось военно-политической стороне похода, его внешнеполитическому фону. В это же время появились первые специальные исторические исследования об истории похода, являющиеся ценными историографическими источниками. Многие из них написаны на основе рукописных документов из личного архива Петра I, часть которых в последующем была утрачена или стала труднодоступной. В советскую эпоху значительно расширяется исследование разных аспектов похода, связанных с его предпосылками и причинами, хозяйственно-экономическим освоением региона, вводятся в научный оборот новые документальные данные. Советские историки придерживались концепции об объективно-прогрессивном значении присоединения прикаспийских регионов к Российской империи, независимо какие бы цели не преследовал царизм. Персидский поход Петра I оценивался как защита кавказских народов от тирании Ирана и Турции. B последние два-три десятилетия в изучении проблемы военно-политической кампании 1722-1723 гг. империи наметились значительные успехи, связанные с разработкой новых сюжетов, с использованием современных исторических подходов и введением в научный оборот колоссального фонда архивных документов и нарративных источников. Вместе с тем, в 1990-е годы наблюдаются попытки ревизии «Персидского похода», замены его новым названием - «Каспийский поход», которое за пределами регионального кавказоведения так и не утвердилось. На современном этапе исследователи углубляют и расширяют имеющиеся научные представления по данной проблеме путем применения таких научных подходов, как история повседневности, военно-историческая антропология. В современной отечественной историографии наметилась тенденция изучения исторической памяти дагестанского общества об образе Петра I, исследования проблемы с позиций российско-персидско-османского пограничья (фронтира), выступавшего не только зоной конфликтности, сопротивления, но и взаимодействия пограничных сообществ и их элит.

Ключевые слова: Петр Великий; Персидский поход 1722-1723 гг.; Низовой корпус; Западный Прикаспий; историография.

(C) Ш.А. Магарамов, 2021

(C) Дагестанский федеральный исследовательский центр РАН, 2021 
The Persian Campaign of 1722-1723 of Peter the Great is the first large-scale foreign policy operation of the Russian state in the East, which led to the establishment of the Russian power in the Caucasus-Caspian region. Today, we are three centuries away from the beginning of this military campaign. The approaching anniversary is a good reason to outline the results in the history of studying this military operation of the Russian Empire. The historiographical comprehension of the problem will make it possible to trace the dynamics of historical thought on the history of the Persian Campaign for almost three centuries, to identify the most poorly developed aspects, to show innovative assessments of authors of different historical eras, to actualize new topics. The relevance of the study is also caused by the lack of a historiographical study, even in the genre of article on the history of the Persian expedition of Peter I. This paper aims at a historiographical analysis of the available scientific literature on the history of the Persian Campaign of Peter I and its results, focuses on controversial aspects and contradictions between concepts and, most importantly, gives the author's opinion on ways to overcome the identified problems and contradictions. The work in no way claims to be a comprehensive solution to this problem, since it is impossible to achieve this within the framework of a single scientific publication due to its limited scope.

The Persian Campaign of Peter I became the starting point in the study of the ethnoculture, history, geography of the Caucasus, i.e. the study of the region went hand in hand with the gradual annexation of its individual parts to the empire. Scientific knowledge was necessary for the successful implementation of military expeditions, for establishing communications for trade and military-political purposes, for creating a more effective management system. At about the same time, the first historical descriptions $[1 ; 2 ; 3]$ of the campaign and the acquired Russian territories in the Caspian were prepared. The scientific significance of these publications lies in the fact that they were written and compiled by the direct participants of the events they describe. When using these works, the subjectivity of the authors' views should be taken into consideration.

In the 18th centuryin the field of humanitarian knowledge, the epochal phenomenon was the creation of the multi-volume work of I.I. Golikov «The Deeds of Peter the Great, the Wise Reformer of Russia», in which documents from the archive of Peter the Great's Cabinet were used for the first time. The description of the Persian Campaign based on documentary material was covered in the eighth part of the book [4].

In the 19th century, due to the Caucasian War that lasted for half a century, interest not only in the events of the war years, but also in the previous military and political actions of Russia in the region increased. The first special historical studies $[5 ; 6 ; 7$; $8 ; 9 ; 10 ; 11 ; 12]$ about the Emperor's campaign in the Caspian region emerge, which are valuable historiographical sources. Many of them were written on the basis of handwritten documents from the personal archive of the tsar, some of which were subsequently lost or became difficult to access. Thus, for example, V.V. Komarov in his work published the part of the text of the military-historical poster of 1779 «Description of the Campaign of Emperor Peter the Great to the Persian provinces 
lying near the Caspian Sea», with illustrations of plans of Caspian cities, fortresses and a map of the Caspian Sea. The archeographic publication of the same poster from the collection of the Manuscript Department of the Library of the Academy of Sciences was carried out by L.L. Muravyeva [13].

The cartographic part and illustrations of the poster have been ignored until recently, while the handwritten text and the map of the Caspian Sea, plans of cities and fortresses make up two closely related parts of the poster of 1779 , compiled on the basis of sources related to the events described [14]. We have managed to fill this gap. In the process of working on the RFBR project «Peter the Great in the historical fate of the Caucasian-Caspian region» in 2020, we identified and published the entire military-historical poster of 1779 in the collection of documents «The Western Caspian Region as part of the Russian Empire (1722-1735): a collection of archival documents. Makhachkala: Mavraev, 2020».

Peter's expedition to the Caspian region was covered in pre-revolutionary historiography in the context of the study of conquest wars and the establishment of Russian power in the Caucasus. In their works, the historians of the 19th century D.P. Buturlin [15], P.G. Butkov [16], V.A. Potto [17; 18] when covering the problem of Russia's eastern policy, focus on the Persian Campaign of Peter I. These studies mainly served a political purpose - to substantiate the incursion and establishment of the Russian Empire in the Caucasus. As we know, the territories conquered by Russia on the western shore of the Caspian Sea were returned to Persia in the mid-30s of the 18th century. The occupation of the Caspian region by Russian troops pursued two goals: the economic one - to seize the Trans-Caucasian route leading to Asia Minor and India, and the political one - to prevent Turkey from reaching the Caspian Sea. The conquered Caspian territories turned out to be unprofitable despite the fact that the «Persian» incomes were slowly but gradually growing. The income did not cover the costs of maintaining the army. When political stabilization came to Persia again, and with it there was a guarantee that the Turks would not be allowed to enter the Caspian region, the Russian Empire considered it necessary to return the conquered Caspian territories to Nadir Shah. This interpretation of the events was suggested by military historians P.G. Butkov, V.A. Potto et al.

The increased interest in the 19th century on the part of official Russian historiography in the Caucasus region, Peter's foreign policy action in particular, led to the publication of a number of documents [19] on this issue, which contain valuable information about Peter's campaign and the presence of the Russian army in the Western Caspian region.

The political aspect of the campaign is covered in E.I. Kozubsky's work on the history of the city of Derbent [20]. The author reports data on the voluntary surrender of the city and the loyalty of the majority of its citizens to the Russians, gives details on the emperor's stay in the city, the appointment of Colonel A.T. Junger as the commandant, the quarter of troops in the fortress and the coastal part of the garrison, about its command structure and functionality. Unfortunately, the author does not provide any justification for the campaign, does not conclude the reasons 
for the withdrawal of Russian troops from the Caspian regions in the mid-3os of the 18th century.

In pre-revolutionary historiography, more attention is paid to the military-political aspect of the Peter the Great campaign, while the issue of economic development of the Caspian territories remained unexplored. At the beginning of the Soviet era, E.S. Zevakin devoted his work to the study of the said aspect [21]. Having published in his work the main items of income and expenses for individual Caspian regions for eight years, from 1723 to 1731 , the author comes to the conclusion about the effectiveness of the empire's economic policy in the region. In his conclusion, the author takes into account only local expenses. In our opinion, if we add the national expenses for ammunition, transport, the construction of military fortifications, as well as the expenditure of manpower, then profitability is out of the question. The unprofitability was largely due to the low level of organization of economic management in the annexed territories. Economic activity was entrusted to the military authorities, who were incompetent in this sphere. No attempts were made to develop new crops, except for viticulture and saffron business in Derbent and its agricultural district, to organize trade and transport. Therefore, the conclusion of E.S. Zevakin, based on incomplete statistical data, should be considered inaccurate.

The first monographic study on the Persian Campaign was the work of historian V.P. Lystsov [7], published on the basis of a Candidate thesis. Basing on documents, mainly from the Russian State Archive of Ancient Acts (RGADA), the author reveals in detail the prerequisites and goals of Peter's campaign to the Western Caspian region, briefly reviews its course, highlights the complex international situation in the region. V.P. Lystsov's monograph is limited by a rather narrow chronological framework - 1722-1723, since a broad chronology would significantly exceed the scope and possibilities of the Candidate's thesis. Moreover, for ideological reasons, the author could not connect the events described with the Treaty of Ganja of 1735, under the terms of which all previous achievements of the Russian Empire were annulled, which ultimately devalued the results of Peter's Persian Campaign. Thus, this work does not fully cover the issue under study.

The book as a whole was received positively by historians, but with some degree of criticism. Working at that time as Dean of the Faculty of History and International Affairs at MGIMO, Candidate of Historical Sciences L.A. Nikiforov published a detailed review in the journal «Voprosy Istorii» (Questions of History) [22]. The reviewer considers unreasonable the author's desire to highlight economic goals and plans of the campaign dictated by the growing «needs of Russia for various raw materials, luxury goods and monetary assets.» This formulation of the question «is very successfully broken down by the author himself, when in the second section of the book he writes about the vulnerability of Russia from the southeast, about the need to secure Russian borders, i.e. about the needs of Russia's defense. It would indeed be more correct to put these reasons for the campaign in the first place.» For this reason, «the first chapter of the book, which contradicts other chapters, should be considered unsuccessful,» the reviewer concludes [22, pp. 106-107]. 
V.P. Lystsov's book, at least for the last six decades, has remained the only monographic study on the Persian Campaign of Peter I, which served as a starting point for developing new aspects of this problem in the subsequent period.

Various issues of the campaign and the stay of the Russian forces on the western coast of the Caspian Sea were covered in the Soviet regional historiography mainly from the standpoint of the joint struggle against Turkish and Iranian claims [23; 24; 25]. The conclusions in these works boil down to the fact that whatever goals tsarism pursued, «the annexation of the Caspian provinces had an objectively progressive significance, protected Dagestan from absorption by Turkey, contributed to the development of the productive forces of the region and the culture of its peoples» [23, p. 124].

Historians of the Transcaucasian republics, such as V.N. Leviatov, P.T. Arutunyan, A.A. Abdurakhmanov, G.B. Abdullaev, G.G. Paychadze, F.M. Aliev [26; 27; 28; 29; $30 ; 31]$ and others consider the problem from a similar point of view. The policy of the Russian Empire in the Caucasus was interpreted by pragmatic considerations as aimed at protecting fellow Armenians and Georgians from Iranian-Turkish oppression; the tsar was seen as a liberator from the tyranny of the Eastern rulers. The authors adhere to the position of the objectively progressive significance of the annexation of the Caucasian regions to the Russian Empire. The abandonment of the Caspian region by Russian troops was explained by the strengthening of Iran, to which the Caspian regions could be handed over safely. The key point was to prevent Turkey to gain access to the Caspian Sea. The last statement was brought back from the prerevolutionary historiographical practice. These works do not take into consideration the goals of the Russian state as a young empire, which sought to establish itself in the Caspian regions and gain its routes to eastern countries.

A significant achievement of the Dagestan historical school of the Soviet era in the study of the problems of Russian-Dagestan relations of the 17th - early 19th century should be considered the creation of two collections of documents [32; 33]. They contain valuable documents from the archives of Moscow, Saint Petersburg, Tbilisi and Makhachkala about the history of centuries-old relations between Russia and the peoples of Dagestan, including the Persian Campaign of 1722-1723 and its results. However, the selection of documents itself raises certain questions; documents on Russian-Dagestan relations that do not correspond to the official Soviet ideology were not included in the collections.

The meeting of one of the influential Dagestani rulers, shamkhal Adil-Girei, with Peter the Great, who declared his loyalty to the tsar, and the emperor's visit to the shamkhal's house in the company of ministers and generals, are described in a small publication by G.S. Fedorov [34], prepared on the basis of the «Expedition Journal of 1722».

During the formation of their own national historiographical principles in the former Soviet Union republics, there were works on the history of the relations of the Transcaucasian peoples with Russia, which radically differed from the Soviet era in their assessments. When describing Peter's policy in the Caspian region, instead of the former «assistance to economic development», protection «from the plunders 
and violence of Iranian invaders and Turkish mercenaries», new, diametrically opposite assessments are given: «invasion», «occupation», "seizure of the territory of the Safavid state and Azerbaijan» [35; 36], and the former assistance from Russia is interpreted as the implementation of its own designs or the desire to "enslave» the Transcaucasian peoples [37]. After the Transcaucasian republics gained sovereignty, their historians tried to show that the plan to include the peoples of the region into the Russian Empire was defective, the accession of non-ethnic territories to the empire was presented from the position of the well-known concept of «absolute evil».

At the turn of the fall of the Soviet and the formation of Russian historiography in connection with the study of the foreign policy history of the North Caucasus of the 18th century, Dagestani historian N.A. Sotavov addressed the problem of the Persian Campaign of Peter the Great. One of the sections of his work is titled «Caspian Campaign of Peter I and its results» [38]. Based on the rich archival material, the author analyzes the difficult Russian-Turkish relations that developed after the emperor's campaign. The campaign itself and the Russian-Iranian Treaty of St. Petersburg of 1723 and the Russian-Turkish Treaty of Constantinople of 1724 signed after it, the author considers the beginning of a new stage of the Russian struggle for the solution of the Caucasian problem [38, p. 67]. Regarding this statement, our standpoint coincides with the opinion of N.A. Sotavov, mainly because Russia at that time took real action in the Caucasus-Caspian region after more than a century. The works of N.A. Sotavov had a significant influence on the works of subsequent generations of historians of Dagestan in terms of covering the history of the Persian campaign and its foreign policy background.

In the early 1990s, instead of the name «Persian Campaign» that was established in historiography, the concept of the "Caspian Campaign» was introduced. For the first time this name was used in Russian historiography by N.I. Pavlenko [39, pp. 429, 432]. After him, N.A. Sotavov widely applies the concept of the «Caspian Campaign». However, the authors do not justify the introduction of the new name of the campaign into science in any way. In all fairness, it should be noted that earlier attempts were made to introduce new names for the campaign - «Caucasian» and «Transcaucasian» ones [40], but to no avail. Analyzing a large body of documents from the federal and state archives of Russia on this issue, we have not found the name «Caspian Campaign» in any of the sources; on the contrary, in the documents the campaign is called the «Persian» or «Nizovoy». In addition, the campaign was undertaken to conquer the regions that at that time were part of Persia or under the sphere of its influence. Therefore, we believe that the definition of the «Caspian Campaign» introduced by the abovementioned authors does not quite correspond to historical reality.

Nevertheless, the name «Caspian Campaign» from the beginning of the 1990 s gradually began to be approved in regional Caucasian studies. From this point of view, the Dagestan scholar-teacher M.R. Gasanov [41; 42] addressed the problem under study, considering this campaign one of the key and fateful stages in the history of Russian-Dagestan relations. 
Similar assessments are also held by the authors of generalizing scientific publications published in the first decade of the new century on the history of the peoples of Dagestan and the North Caucasus, their centuries-old relations and integration with Russia [43; 44; 45]. In these works, along with outdated Soviet approaches to assessing the results of the campaign, there are also new interpretations. Thus, the abandonment of the Caspian regions by Russia in the mid-30s of the 18th century is explained by «the economic unprofitability of preserving remote and poor North Caucasian lands as part of the Russian state.» At the same time, the political factor is taken into account: «Russia's relations with its long-time rivals, Iran and the Ottoman Empire, were also affected by the changed balance of power in the European arena» [45, p. 43].

In the post-Soviet Russian historiography, there is an increased interest in Peter's campaign in the Caspian Sea, as evidenced by publications prepared on the basis of new documentary data on the situation of the Nizovoy Corps [46;47;48; 49], established for the management and integration of the region into the Russian economic, political and legal space. In these publications, the source base of the problem is significantly expanded. In one of his publications, M.A. Polievktov introduces a valuable archival document in German, titled «Remarks tending to the true benefit of your Majesty in those conquered Persian provinces that, according to Persian treatises, remained with his Majesty of Russia.» The document is an official memorandum, compiled on behalf of the official authorities, on the possibility of raising the profitability of the Caspian regions, primarily Baku and Derbent, which became part of the Russian Empire. According to the researcher's suggestion, the author of the memo was J.G. Gerber, who compiled it in 1732 [49, pp. 527-534, 536] after the abandonment of Gilan by the Russian troops. Unfortunately, this project, which provided for a whole range of measures to increase revenues from the Caspian regions, remained on paper and did not affect the economic management of the «newly conquered» regions.

The Candidate's dissertations of the last two or three decades on various aspects of the history of the Caucasus and its relations with Russia in the first half of the 18th century clearly show the increased interest in the topic of the Persian campaign of Peter the Great $[50 ; 51 ; 52 ; 53 ; 54 ; 55]$. Many of them remain committed to Soviet approaches, and the emperor's campaign is seen as the protection of the Caucasian peoples from the tyranny of Iran and Turkey, the strengthening of the south-eastern borders; some authors even attribute a defensive nature to the campaign.

A significant contribution to the historiography of the Persian Campaign and its results was made by the prominent Russian historian I.V. Kurukin $[56 ; 57 ; 58 ; 59 ; 60$; 61]. Based on new documentary data from the federal archives of the country, various aspects of the problem related to the system of the imperial experience in managing the region, building contacts between Russians and the local population are explored. As a result of the research, the author comes to a very important conclusion that «the Russian troops scattered over a considerable area faced rejection of foreign domination in a country with stable traditions of statehood and could hardly maintain order in the occupied provinces,» and as a result «the young (Russian - auth.) empire was not 
yet ready for the development of remote Caspian provinces and their management» [58, p. 768]. This conclusion, which differs significantly from those made by previous researchers, is characterized by innovation and is justified by documentary data.

The campaign of Peter I in 1722-1723 to the Western Caspian region and the Caucasus, which led to the conquering of the region, as well as the subsequent fate of the Nizovoy Corps and the policy of Russia in this region until the end of the 18th century became the subject of an in-depth study in the monographic work of I.V. Kurukin [61]. This is the second monograph in Russian historiography after the work of V.P. Lyssov on the history of the Persian Campaign of Peter I and its results. The monograph is distinguished by a solid source base, a combination of documents from federal archives with rare published sources and little-known historiography. Using modern historical approaches, the author examines a wide range of issues related to the military-political campaign of 1722-1723, the conclusion of international treaties with Iran (1723) and Turkey (1724), the establishment of the RussianTurkish border, the activities of the Nizovoy (Persian) Corps for the management and economic development of the empire of the western shores of the Caspian region, the everyday life of Russian officers and soldiers. Many author's generalizations were the result of the search, identification and analysis of documentary data. Among them, in particular, is the idea that «Peter's plans, as in many other cases, were ahead of their time. The country did not yet have economic opportunities for large-scale development of overseas territories, and the tsar's call to 'build companies' did not receive a response; Cossacks and soldiers could not replace energetic businessmen, sailors, merchants, shipowners, who were scarce in Russia itself» [62, p. 274].

Military events in Dagestan during the stay of the imperial army in the region, in particular punitive expeditions against shamkhal Tarkovsky Adil-Girei, according to I.V. Kurukin, marked the beginning of the Caucasian War. The author considers «it fair the existence of more than one (Caucasian war. - auth.), and several such wars in the period from 1722 to the suppression of the last great uprising in Chechnya and Dagestan in 1878, more precisely, not so much the actual wars as the coupling of diverse and different-time conflicts related to the problems of internal development of highland societies, their resistance to Russian advance into the Caucasus, the struggle of the Russian authorities with raids, interethnic contradictions and continuous strife, finally, with the clash of various civilizations and the struggle for the division of Transcaucasia between the great powers» [63, p. 10 ]. The attribution of the beginning of the Caucasian War to the events of the Peter's era in the Caucasus emerged in the works of pre-revolutionary authors. Thus, V.A. Potto drew attention to the fact that «if Russia's relations with the Caucasus date back to the oldest times of our history, then the first steps towards its lasting conquest were taken by Peter the Great, who pointed out to Russia the global objectives that it faced in the Near Asian East in the future» [63]. If we proceed from this view, then it should be noted that in the previous period, in particular at the turn of the 16-17th centuries, armed clashes between Russian troops and Dagestani detachments took place, that it was from this time that Russia's advance into the Caucasus started. As for the Caucasian War, it 
should be considered as an independent process, as it has already been established in historiography, following the incorporation of the Caucasian region into the Russian Empire, or as the final stage of annexation, with a specific chronological framework.

Various aspects of the stay of the Russian army in Dagestan in 1722-1735 were reflected in the monograph and numerous publications of the Dagestani historian N.D. Chekulaev $[64 ; 65 ; 66 ; 67 ; 68 ; 69 ; 70 ; 71 ; 72 ; 73 ; 74]$, some of which were prepared in collaboration with other researchers. The author's research practice has shown that regional archives, in particular the Central State Archive of the Republic of Dagestan, contain a large number of valuable documents about the activities of the Nizovoy Corps in the Western Caspian region. N.D. Chekulaev and co-authors provide information on the recruitment, food and medical support of the regiments of the Russian army. Based on the documentary data, the role of the Terek Cossacks in the Caucasian policy of the empire, the issues of commandant service and the administration of justice in individual garrisons are considered.

With all the value of N.D. Chekulaev's publications, among them there are also those in which the old pre-revolutionary approaches are reanimated. Following Professor I.V. Kurukin, the author places the two-century history of the Russian-Caucasian confrontation into the concept of the "Caucasian War», attributing the beginning of the war to 1725-1726, when a series of punitive expeditions were undertaken under the leadership of Major General G.S. Kropotov against the Dagestan ruler Shamkhal Adil-Girei, who had betrayed the tsar [74].

Publications of E.I. Inozemtseva are devoted mostly to the economic policy of the Russian state in the Caucasus in the 18 th century $[75 ; 76 ; 77 ; 78]$. Combining the archival documents with narrative sources, she managed to explore the role and importance of the Caspian trade route and the Caspian Sea as a contact zone in the formation and development of economic relations between the Russian Empire and its eastern neighbors, to show the organization of safe navigation in the Caspian region, the creation of trade infrastructure, to show the process of integration of the Western Caspian region into the Russian economic system.

An important direction in the historiography of the problem under question has recently become the study of the role of the nomadic and settled peoples of southern Russia as allies of the Russian government in the Caucasus. A number of publications discuss the role of Cossacks and Kalmyks in the Russian military company in the Western Caspian region in the first third of the 18 th century $[77 ; 79 ; 80 ; 81$ ]. As we know, irregular forces acted as punitive detachments against the rebellious Caucasian and Persian rulers. Kalmyk historian V.T. Tepkeev shows the ambiguity of the policy of the Kalmyk Khan Ayuki, when he simultaneously participated as an ally in the campaign of the Russian army in Derbent, and at the same time continued to maintain good-neighborly relations with those Dagestani rulers who opposed the Russian government. When the leaders of the Kalmyk army were ordered to pursue the inhabitants of Endirey who resisted the army of Peter I, the Kalmyks secretly warned them «to hide wherever they can» [82, p. 18]. However, it should be noted that V.T. Tepkeev uses the new name «Derbent Campaign» to label the military 
campaign of 1722 , which by semantics cannot cover the essence of the militarypolitical operation of Peter the Great.

N.N. Garunova's study is devoted to the problems of the implementation of the Caucasian policy of the Russian Empire and the role of Russian fortress cities in this process, including those founded in the Peter's era [83; 84]. The researcher examines the role of the Tersk town and the fortress of the Holy Cross (the latter was founded by the personal order of Emperor Peter the Great) as Russian outposts in the Caucasus, as well as the problems of the colonization and resettlement policy of the empire in the region. A notable phenomenon in the historiography of the problem under study was another publication by N.N. Garunova, which is dedicated to the general-in-chief V. Ya. Levashov [85] during his stay in the Caucasus.

The historiography of the personalities participating in Peter's campaign of 1722-1723 and the figures of the Nizovoy Corps still remains a poorly developed historiographical topic. Historical personalism in scientific research, methodologically related to the problem of the role of personality in history, can be a promising direction in the study of the stated problem.

The actualization of not only certain aspects, but also the entire problem of the Persian campaign of 1722-1723 is evidenced by holding the international scientific conference «The Caucasus and the Middle East: from the Caspian campaign of Peter I to the collapse of the Nadir Shah power» in Makhachkala in 2020, dedicated to the 290th anniversary of the campaign, with a subsequent publication of the collection of articles. Among a large number of publications, we highlight the papers of N.A. Sotavov "The Caucasian campaigns of Peter I and Nadir Shah Afshar and their consequences for the peoples of the region» [86], A.M. Magomeddadaev, Z.M. Amirov «The AzovCaspian campaigns of Peter I in the context of international politics and the invasion of Nadir Shah in the Caucasus» [87], in which the Persian campaign is considered in the context of a complex international situation in the region, in conjunction with other foreign policy companies of the emperor.

In the publication of the Chechen historian Sh.A. Gapurov [88] the campaign of Peter I is considered from the point of view of foreign authors. The author comes to the conclusion that «almost all foreign historians agree mainly with the opinion of domestic authors about the goals of Peter the Great's Caspian campaign: to get access to the Caspian Sea, establish trading posts on its coast, establish trade relations with India and other eastern countries through the Caspian Sea, turn the Persian silk trade route to Europe, which ran through Turkey and Turkish possessions to Russia, turning it into a transshipment point for eastern trade with Europe and, finally, prevent Turkey from reaching the Caspian Sea, seizing the Caspian coast, which would pose a serious threat to Russia's southern borders.» As for the reasons for the unexpected retreat of the emperor himself and his army, foreign authors tend to consider «the threat of war with Turkey as the most important reason» [88, p. 68]. This, in particular, was mentioned by some Russian historians such as V.P. Lystsov, O.P. Markov, N.A. Sotavov with reference to Turkish authors. On this issue, the historian I.V. Kurukin writes that «the decrees and other papers at our disposal 
from Peter's Cabinet do not contain information about the arrival of any of the Turkish diplomats to the Russian camp; this topic was not raised among the generals at the "council» held in the camp [62, p. 102]. In addition to that, we conducted comprehensive research on Peter's legacy in the history of the Caucasus within the framework of the RFBR grant and failed to find any documents on this subject in the central and regional archives. Thus, the idea that the Emperor's campaign was interrupted due to the threat of war with the Turks, which migrated from the works of Turkish authors to the works of domestic historians, has no documentary evidence.

The foundations of the Eastern policy of Peter the Great occupy an important place in the modern Russian historiographical discourse. This is evidenced by the XI International Petrovsky Congress «Peter I and the East» held in St. Petersburg in 2018, which resulted in a collection of articles. The first section of the collection "Caspian region and Persia» of twelve papers covers a wide range of issues of the emperor's policy in the Caspian region. At least six papers of this collection are devoted to the Persian campaign. These are publications of the Rostov historian P.A. Avakov [89] on the participation of the Don Cossacks in the campaign, Dagestan historians M.S. Gadzhiev, E.I. Inozemtseva, N.D. Chekulaev [90] about the Derbent garrison of the Nizovoy Corps, N.M. Speranskaya [91] about the journal of the Persian campaign from the Voltaire library, etc., which are distinguished by a solid source base, innovative approaches and assessments of the problem under study.

The most informative is the article by the leading archivist and historian T.A. Lapteva [92], written on the basis of documents of the collection of the «Cabinet of Peter the Great» from RGADA. The publication reviews the activities of the commandant of the Derbent garrison of the Nizovoy Corps, Colonel A.T. Junger («the nestling of Peter's nest») for the management and economic development of Derbent and its surroundings, one of the few who continued the work of the emperor after his death. Documents published as an appendix to the article, present the correspondence of the commandant with the Cabinet Secretary A.V. Makarov, reveal the commandant A.T. Junger as an experienced and efficient manager who cares about the affairs of the empire in the Caspian regions.

The stay of Peter the Great in Derbent during the Persian Campaign is considered in the article by archaeologist M.S. Gadzhiev [93]. In addition, the publication provides graphic materials and photographs of the 19th - early 20th century, depicting the dugout of Peter I and the columned building above it, provides an overview of archaeological research at the site «The House of Peter I» in Derbent.

The issue of Peter the Great's campaign of 1722-1723 and its results has recently been touched upon in monographic studies by Dagestan Caucasiologist in connection with the coverage of issues of the Caucasian policy of the Russian state, international relations in the North-Eastern Caucasus in the 18th - early 19th centuries [94; 95; 96].

The political situation in Dagestan and the foreign policy of its rulers on the eve of the campaign are investigated in the article by Sh.A. Magaramov [97]. F.N. Orudzhev's paper is devoted to the study of the influence of Peter's campaign on the process of formation and strengthening of the pro-Russian orientation of Dagestan political elites [98]. 
Currently, there is an actualization of source studies on the problem under question due to the two major dates: in 2022, the 350th anniversary of the birth of Peter the Great and the 30oth anniversary of the Persian Campaign. In 2020, a collection of archival documents and materials, prepared by Dagestan historians E.I. Inozemtseva, Sh.A. Magaramov and N.D. Chekulaev [99], was published, which include about 300 original documents from the state and federal archives of Russia. The documents were introduced into science for the first time and make it possible to reconstruct the Russian imperial policy in the Western Caspian Region in 1722-1735 in the international context. The collected documents highlight the imperial experience of management and economic development of the region, the system of interaction with local elites, reveal the daily life of Russian officers and soldiers on the coasts of the Caspian Sea, difficulties in the functioning of the Nizovoy Corps associated with the natural factor and the ethnopolitical composition of the region.

The authors published a series of scientific papers on various aspects of the activities of Peter I and the Nizovoy Corps in the Caspian region. Among them are publications devoted to the financial and economic activities of the Derbent garrison of the Imperial troops $[100 ; 101]$ and Peter the Great's unfulfilled plans to create a network of trade communications and infrastructure in the Western Caspian region [102]. We should also mention the joint publication of F.A. Polchaeva and D.A. Kasymov, in which they recreate the image of Peter I in the historical memory of the Dagestan population. The innovative ideas of the authors in the formulation of the problem should also be noted. Their study reveals the ambiguity of the perception of the personality of Peter the Great by the modern Dagestan society: «On the one hand, Peter the Great is an invader who burned settlements (in Utamysh and Endirei), ravaged villages (in the Lower Kaitag) and brutally killed their population. On the other hand, he is a great politician who influenced the development of the Russian state for many decades to come, who played a positive role in the development of Russian-Dagestan relations. Despite these diametrically opposed opinions, the image of Peter I in the historical memory of the peoples of Dagestan has formed a fundamentally positive one» [103, p. 897].

Thus, the analysis of the entire complex of historiographical sources published for almost three centuries shows that significant progress has been made in the study of the Persian Campaign of 1722-1723 and its results. At the same time, the assessments and conclusions of the authors of the pre-revolutionary and Soviet eras were made following the prevailing ideological lines in the country. In the last three decades, due to the methodological evolution of research approaches, it has become possible to take a fresh look at the seemingly already established assessments of Peter the Great's military-political campaign in the Caspian region. A large fund of sources has been introduced into science, which make it possible to develop as independent aspects problems related to the economic development of the empire of the Western Caspian region, the activities of individual personalities, the reaction of the Caucasian and Persian rulers to new political realities. There is a tendency in modern historical science to study the problem from the standpoint of the Russian-Persian-Ottoman frontier, which acted not only as a zone of conflict, resistance, but also the interaction 
of frontier communities and their elites. A promising direction may be the study of the reflection of the events of those years in the historical memory of the population of the Caucasus-Caspian region, including the image of Peter the Great and his generals - M.A. Matyushkin, V.V. Dolgorukov, V.Ya. Levashov and others, who were the direct agents of Russian policy in the Caspian region. Conditions are being created for studying the problem using such methodological approaches as the history of everyday life, military-historical anthropology, historical personalism.

Acknowledgements. This study was financially supported by the Russian Fund for Fundamental Research through the scientific projects №20-19-50087 "Historiography of the Persian Campaign of 1722-1723 of Peter the Great and its results (to the 30oth anniversary of the campaign)" and № 20-09-42023 "Peter the Great in the historical fate of the Caucasus-Caspian Region".

\section{REFERENCES}

1. Gadzhiev VG. The work of J. Gerber «Description of the lands and peoples between Astrakhan and the Kura River» as a historical source on the history of the peoples of the Caucasus [Sochinenie I. Gerbera «Opisanie stran i narodov mezhdu Astrakhan'yu i rekoi Kuroi nakhodyashchikhsya» kak istoricheskï istochnik po istorï narodov Kavkaza]. Moscow: Nauka, 1979. (In Russ)

2. Gerber IG. Description of lands and peoples along the western coast of the Caspian Sea, 1728. History, geography and ethnography of Dagestan in the XVIII-XIX centuries. Archival materials [Opisanie stran i narodov vdol' zapadnogo berega Kaspiiskogo morya, 1728 g.]. Moscow: Vostochnaya Literatura Publ., 1958:60-120. (In Russ)

3. Soymonov FI. Description of the Caspian Sea and the Russian conquests, as part of the history of the Emperor Peter the Great [Opisanie Kaspiiskogo morya i chinennykh na onye rossiiskie zavoevaniya, yako chast' istorii gosudarya imperatora Petra Velikogo]. St. Petersburg: Imperial Academy of Sciences, 1763. (In Russ)

4. Golikov II. Deeds of Peter the Great, the wise reformer of Russia [Deyaniya Petra Velikogo, mudrogo preobrazitelya Rossii]. Part VIII. Moscow, 1789. (In Russ)

5. Komarov VV. Persian War of 1722-1725 [Persidskaya voina 1722-1725 gg.]. Moscow: Katkov and Co., 1867. (In Russ)

6. Brief chronicle of the wars waged by the Russians against the Persians. Notes of the Fatherland [Kratkaya letopis' voinam, vedennym russkimi protiv persiyan // Otechestvennye zapiski]. St. Petersburg: K. Kraya Typography, 1827. (In Russ)

\section{СПИСОК ЛИТЕРАТУРЫ}

1. Гаджиев В.Г. Сочинение И. Гербера «Описание стран и народов между Астраханью и рекой Курой находящихся» как исторический источник по истории народов Кавказа / В. Г. Гаджиев. - М.: Наука, 1979. - 272 с.

2. Гербер И.Г. Описание стран и народов вдоль западного берега Каспийского моря, 1728 г. / И. Г. Гербер // История, география и этнография Дагестана XVIII-XIX вв. Архивные материалы. - М.: Изд-во вост. лит., 1958. - С. 60-120.

3. Соймонов Ф.И. Описание Каспийского моря и чиненных на оном российские завоевания, яко часть истории государя императора Петра Великого / Ф. И. Соймонов. - СПб.: Имп. Акад. наук, 1763. - 380 с.

4. Голиков И.И. Деяния Петра Великого, мудрого преобразителя России / И. И. Голиков. - Ч. VIII. - М.: Унив. тип., у Н. Новикова, 1789. $-449 \mathrm{c}$.

5. Комаров В.В. Персидская война 17221725 гг. / В. В. Комаров. - М.: Тип. «Катков и $\mathrm{K}^{\circ} », 1867 .-68 \mathrm{c}$.

6. Краткая летопись войнам, веденным русскими против персиян // Отечественные записки. - СПб.: Тип. К. Крайя, 1827. Ч. 32. - 528 с.

7. Лъсијов В.П. Персидский поход Петра I: 1722-1723 / В. П. Лысцов. - М.: МГУ, 1951. 248 c.

8. Мельгунов Г.В. Поход Петра Великого в Персию / Г. В. Мельгунов // Русский вестник. - 1874. - Т. 110. - С. 5-60.

9. О Персидском походе при государе Петре Великом бывшем // Русский архив. 1899. - № 12. - C. 481-491. 
7. Lystsov VP. Persian campaign of Peter I: 1722-1723 [Persidskii pokhod Petra I: 1722-1723] Moscow: MSU, 1951.(In Russ)

8. Melgunov GV. The campaign of Peter the Great to Persia [Pokhod Petra Velikogo $v$ Persiyu]. Russian Journal. 1874, 110: 5-60. (In Russ)

9. On the Persian campaign under the former Tsar Peter the Great [O Persidskom pokhode pri gosudare Petre Velikom byvshem]. Russian archive. 1899, 12: 481-491. (In Russ)

10. Soloviev SM. Peter the Great on the Caspian Sea [Solov'ev S.M. Petr Velikii na Kaspiiskom more]. Bulletin of Europe. 1868, 2: 163-202.

11. Tumansky F. Description of the campaign of Tsar Peter the Great to the Persian provinces lying at the Caspian Sea [Opisanie pokhoda gosudarya Petra Velikogo $k$ lezhashchim pri Kaspiiskom more persidskim provintsiyam]. Russian journal. 1793, 3: 45-76. (In Russ)

13. Muravyova LL. Military-historical poster of the 18th century about the Persian campaign of Peter I. Archeographic Yearbook for 1961 [Voenno-istoricheskii plakat XVIII veka o Persidskom pokhode Petra I]. Moscow, 1962:393-415. (In Russ)

14. Goldenberg LA. Handwritten maps and plans of the 18th century. as a source on the history of the city of Derbent. Archeographic Yearbook for 1963 [Rukopisnye karty i plany XVIII v. kak istochnik po istorii goroda Derbenta]. Moscow: Nauka, 1964:115-140. (In Russ)

15. Buturlin DP. Military history of the campaigns of Russians in the 18th century [Voennaya istoriya pokhodov rossiyan $v$ XVIII stoletii]. St. Petersburg: Military Typography of the General Staff of His Imperial Majesty, 1823. Vol. 4, Part 2.

16. Butkov PG. Materials for the new history of the Caucasus from 1722 to 1803 [Materialy dlya novoi istorii Kavkaza s 1722 po 1803 god]. Part 1. St. Petersburg: Imperial Academy of Sciences, 1869. (In Russ)

17. Potto VA. Historical study of the Caucasian wars from their beginning to the annexation of Georgia [Istoricheskii ocherk Kavkazskikh voin ot ikh nachala do prisoedineniya Gruzii]. Tiflis, 1899. (In Russ)

18. Potto VA. The Caucasian War in Selected Works, Episodes, Legends and Biographies [Kavkazskaya voina $v$ otdel'nykh ocherkakh, epizodakh, legendakh i biografiyakh]. St. Petersburg, 1887. Vol. 1. (In Russ)

19. Materials for the history of the Russian fleet [Materialy dlya istorii russkogo flota]. St. Peters-
10. Соловъев С.M. Петр Великий на Каспийском море / С. М. Соловьев // Вестник Европы. - 1868. - Т. II. - C. 163-202.

11. Туманский Ф. Описание похода государя Петра Великого к лежащим при Каспийском море персидским провинциям / Ф. Туманский // Российский магазин. - 1793. Ч. 3. С. $45^{-76 .}$

12. Лебедев В.И. Западный берег Каспийского моря при Петре Великом / В.И. Лебедев // Журнал Министерства народного просвещения. - 1848. - № 7. - С. 1-17.

13. Муравъева Л.Л. Военно-исторический плакат XVIII века о Персидском походе Петра I / Л. Л. Муравьева // Археографический ежегодник за 1961 год. - М., 1962. С. 393-415.

14. Гольденберг Л.А. Рукописные карты и планы XVIII в. как источник по истории города Дербента / Л.А. Гольденберг // Археографический ежегодник за 1963 г. - М.: Наука, 1964. - C. $115-140$.

15. Бутурлин Д.П. Военная история походов россиян в XVIII столетии / Д. П. Бутурлин. - СПб.: Военная Тип. Главного Штаба Его Императорского Величества, 1823. Т. 4. Ч. 2. $-266 \mathrm{c}$.

16. Бутков П.Г. Материалы для новой истории Кавказа с 1722 по 1803 год / П.Г. Бутков. - Ч. 1. - СПб.: Тип. Императ. Акад. наук, 1869. $-548 \mathrm{c}$.

17. Потто В.A. Исторический очерк Кавказских войн от их начала до присоединения Грузии / В. А. Потто. - Тифлис: Воен.-ист. отд. при Штабе Кавк. воен. окр., 1899. - 332 с.

18. Потто В.А. Кавказская война в отдельных очерках, эпизодах, легендах и биографиях / В. А. Потто. - СПб.: Тип. Е. Евдокимова, 1887. T. 1. $-737 \mathrm{c}$.

19. Материалы для истории русского флота. - СПб.: Тип. Морского Министерства, 1867. Ч. IV. $-740 \mathrm{c}$.

20. Козубский Е.И. История города Дербента / Е. И. Козубский. - Темир-Хан-Шура: «Русская тип.» В.М. Сорокина, 1906. - 468 с.

21. Зевакин E.C. Прикаспийские провинции в эпоху русской оккупации XVIII века / Е. С. Зевакин // Известия общества обследования и изучения Азербайджана. - Баку: б/и, 1927. - C. $123-133$.

22. Никифоров Л.И. В. П. Лысцов. Персидский поход Петра I (1722-1723) / Л. И. Никифоров // Вопросы истории. - 1952. - № 4. C. $105-108$. 
burg: Marine Ministry, 1867. Part IV. (In Russ) 20. Kozubsky EI. History of the city of Derbent [Istoriya goroda Derbenta]. Temir-Khan-Shura, 1906. (In Russ)

21. Zevakin ES. The Caspian provinces in the era of the Russian occupation of the 18th century [Prikaspiiskie provintsii $v$ epokhu russkoi okkupatsii XVIII veka]. News of the Society for Survey and Study of Azerbaijan. Baku,1927:123-133. (In Russ)

22. Nikiforov LI, Lystsov VP. The Persian campaign of Peter I (1722-1723) [Persidskii pokhod Petra I (1722-1723)]. Questions of history. 1952, 4: 105-108. (In Russ)

23. Gadzhiev VG. The role of Russia in the history of Dagestan [Rol' Rossii v istorii Dagestana]. Moscow: Nauka, 1965. (In Russ)

24. History of Dagestan [Istoriya Dagestana]. Moscow: Vostochnaya literatura, 1967. (In Russ)

25. The history of the peoples of the North Caucasus from ancient times to the end of the 18th century [Istoriya narodov Severnogo Kavkaza s drevneishikh vremen do kontsa XVIII v.]. Moscow: Nauka, 1988. (In Russ)

26. Leviatov VN. Studies on the history of Azerbaijan in the 18th century [Ocherki iz istorii Azerbaidzhana $v$ XVIII $v$.]. Baku: Publishing house of the Academy of Sciences of the Azerbaijan SSR, 1948. (In Russ)

27. Arutunyan PT. Liberation movement of the Armenian people in the first quarter of the 18th century [Osvoboditel'noe dvizhenie armyanskogo naroda $v$ pervoi chetverti XVIII $v$.]. Moscow: Academy of Sciences of the USSR, 1954. (In Russ)

28. Abdurakhmanov AA. Azerbaijan in the relationship between Russia, Turkey and Iran in the first half of the 18th century [Azerbaidzhan vo vzaimootnosheniyakh Rossii, Turtsii i Irana $v$ pervoi polovine XVIII v.]. Baku: Academy of Sciences of the Azerbaijan SSR, 1964. (In Russ)

29. Abdullaev GB. Azerbaijan in the 18th century and its relationship with Russia [Azerbaidzhan $v$ XVIII veke i vzaimootnosheniya ego s Rossiei]. Baku: Academy of Sciences of the Azerbaijan SSR, 1965. (In Russ)

30. Paichadze GG. Russian-Georgian political relations in the first half of the 18th century [Russko-gruzinskie politicheskie otnosheniya $v$ pervoi polovine XVIII v.]. Tbilisi: Sabchota Sakartvelo, 1970. (In Russ)

31. Aliev FM. Anti-Iranian demonstrations and the struggle against the Turkish occupation in Azerbaijan in the first half of the 18th century [An-
23. Гаджиев В.Г. Роль России в истории Дагестана / В. Г. Гаджиев. - М.: Наука, 1965. $-392 \mathrm{c}$.

24. История Дагестана. - М.: Восточная литература, 1967. Т. І. -436 с.

25. История народов Северного Кавказа с древнейших времен до конца XVIII в. - М.: Наука, 1988. - 543 с.

26. Левиатов В.Н. Очерки из истории Азербайджана в XVIII в. / В.Н. Лебедев. Баку: Изд-во АН АзССР, 1948. - 227 с.

27. Арутунян П.Т. Освободительное движение армянского народа в первой четверти XVIII в. / П.Т. Арутунян. - М.: Изд-во АН CCCP, 1954. - $304 \mathrm{c}$.

28. Абдурахманов А.А. Азербайджан во взаимоотношениях России, Турции и Ирана в первой половине XVIII в. / А. А. Абдурахманов. - Баку: Изд-во АН АзССР, 1964. - 97 с.

29. Абдуллаев Г.Б. Азербайджан в XVIII веке и взаимоотношения его с Россией / Г.Б. Абдуллаев. - Баку: Изд-во АН АзССР, 1965. - $621 \mathrm{c}$.

30. Пайчадзе Г.Г. Русско-грузинские политические отношения в первой половине XVIII в. / Г. Г. Пайчадзе. - Тбилиси: Сабчота Сакартвело, 1970. - 280 с.

31. Алиев Ф.М. Антииранские выступления и борьба против турецкой оккупации в Азербайджане в первой половине XVIII в. / Ф.М. Алиев. - Баку: Элм, 1975. - 231. с.

32. Русско-дагестанские взаимоотношения в XVII - первой четверти XVIII вв. (Документы и материалы). - Махачкала: Даг. кн. изд-во, 1958. - 336 с.

33. Русско-дагестанские взаимоотношения в XVIII - начале XIX в.: сборник документов. - М.: Наука, 1988. - 357 с.

34. Федоров Г.С. Некоторые эпизоды из истории похода Петра I на Кавказ / Г.С. Федоров // Русско-дагестанские взаимоотношения в XVI - начале XX в. - Махачкала: Даг. фил. АН СССР, 1988. - С. 84-86.

35. Мустафазаде T.T. Азербайджан и русско-турецкие отношения в первой трети XVIII в. / Т. Т. Мустафазаде. - Баку: Элм, 1993. $-240 \mathrm{c}$.

36. Гезалова Н.P. Вопросы истории Азербайджана XVIII в. (На основе сведений англоязычных источников и историографии) / Н.Р. Гезалова. - М.: ИРИС Групп, 2010. - 241 c. 
tiiranskie vystupleniya i bor'ba protiv turetskoi okkupatsii $v$ Azerbaidzhane $v$ pervoi polovine XVIII v.]. Baku: Elm, 1975. (In Russ)

32. Russian-Dagestan relations in the XVII first quarter of the XVIII centuries. (Documents and materials) [Russko-dagestanskie vzaimootnosheniya $v$ XVII - pervoi chetverti XVIII vv. (Dokumenty $i$ materialy)]. Makhachkala: Dagbook Publ., 1958. (In Russ)

33. Russian-Dagestan relations in the 18th - early 19th centuries: collection of documents [Russko-dagestanskie vzaimootnosheniya $v$ XVIII - nachale XIX v.: sbornik dokumentov]. Moscow: Nauka, 1988. (In Russ)

34. Fedorov GP. Some episodes from the history of Peter I's campaign to the Caucasus. Russian-Dagestan relations in the 16th - early 2oth centuries [Nekotorye epizody iz istorii pokhoda Petra I na Kavkaz / G. S. Fedorov // Russko-dagestanskie vzaimootnosheniya $v X V I-n a-$ chale $X X v$.]. Makhachkala: Dag. Phil. Academy of Sciences of the USSR, 1988:84-86. (In Russ)

35. Mustafazade TT. Azerbaijan and Russian-Turkish relations in the first third of the 18th century [Azerbaidzhan i russko-turetskie otnosheniya $v$ pervoi treti XVIII v.]. Baku: Elm, 1993. (In Russ)

36. Gezalova NR. Issues of the history of Azerbaijan in the 18th century (Based on information from English-language sources and historiography) [Voprosy istorii Azerbaidzhana XVIII v. (Na osnove svedenii angloyazychnykh istochnikov $i$ istoriografii)]. Moscow: IRIS Group, 2010.

37. Vachnadze M. History of Georgia (from ancient times to 1801) [Istoriya Gruzii (s drevneishi$k h$ vremen do $1801 \mathrm{~g}$.)]. Tbilisi: Intellect, 2004.

38. Sotavov N-PA. The North Caucasus in Russian-Iranian and Russian-Turkish relations in the 18th century: From the Treaty of Constantinople to the Kuchuk-Kainardzhiyskiy peace, 1700-1774 [Severnyi Kavkaz v russko-iranskikh i russko-turetskikh otnosheniyakh $v$ XVIII v.: Ot Konstantinopol'skogo dogovora do Kyuchuk-Kainardzhïskogo mira, 1700-1774 gg.]. Moscow: Nauka, 1991. (In Russ)

39. Pavlenko NI. Peter the Great [Petr Velikii]. Moscow: Mysl, 1990. (In Russ)

40. Fadeev AV. Russia and the Caucasus in the first third of the 19th century [Rossiya $i$ Kavkaz $v$ pervoi treti XIXv.]. Moscow: Publishing house of the Academy of Sciences of the USSR, 1961. (In Russ)

41. Gasanov MR. The Caspian campaign of Peter I - an important stage in the development of
37. Вачнадзе М. История Грузии (с древнейших времен до 1801 г.) / М. Вачнадзе, В. Гурули, М. Бахтадзе. - Тбилиси: Интелект, 2004. - $260 \mathrm{c}$.

38. Сотавов Н.-П.А. Северный Кавказ в русско-иранских и русско-турецких отношениях в XVIII в.: От Константинопольского договора до Кючук-Кайнарджийского мира, 1700-1774 гг. / Н.-П. А. Сотавов. - М.: Наука, 1991. $-224 \mathrm{c}$.

39. Павленко Н.И. Петр Великий Н.И. Павленко. - М.: Мысль, 1990. - 591 с.

40. Фадеев А.В. Россия и Кавказ в первой трети XIX в. / А. В. Фадеев. - М.: Изд-во АН CCCP, 1961. - $398 \mathrm{c}$.

41. Гасанов М.P. Каспийский поход Петра I - важный этап в развитии русско-дагестанских отношений / М. Р. Гасанов // Научная мысль Кавказа. - 1995. - № 2. - С. 67-71.

42. Гасанов М.Р. Каспийский поход Петра I 1722-1723 гг. - один из важных этапов в развитии русско-дагестанских взаимоотношений / М.Р. Гасанов. Махачкала: Эпоха, 2015. - $111 \mathrm{c}$.

43. История многовековых взаимоотношений и единения народов Дагестана с Россией. К 150-летию окончательного вхождения Дагестана в состав России. Махачкала: ИИАЭ ДНЦ РАН, 2009. - $752 \mathrm{c.}$

44. История народов Дагестана с древнейших времен до наших дней. Т. 1. - М.: Наука, 2004. -627 c.

45. Северный Кавказ в составе Российской империи. - М.: Новое лит. обозрение, 2007. $-460 \mathrm{c.}$

46. Дуров И.Г. Провиантское обеспечение русской армии и флота в Персидском походе 1722-1723 гг. / И. Г. Дуров // Кров. Порох. Лавры: Войны России в эпоху барокко (17001762). Вып. І. - СПб.: б \и, 2002. - С. 37-44.

47. Петрухинцев Н.Н. Опальный фельдмаршал / Н. Н. Петрухинцев // Родина. 1993. - № 12. - С. 34-37.

48. Петрухинцев Н.Н. Проект Бругемана и русская оккупация прикаспийских областей в двадцатых годах XVIII века / Н.Н. Петрухинцев // Каспийский транзит. - М.: ДиДик Танаис, 1996. Т. 2. Вып. 5-6. - С. 566-581.

49. Полиевктов М.А. Выход к морю / М.А. Полиевктов // Каспийский транзит. - М.: Ди-Дик Танаис, 1996. Т. 2. Вып. 5-6. С. $522-548$. 
Russian-Dagestan relations [Kaspiiskii pokhod Petra I - vazhnyi etap v razvitii russko-dagestanskikh otnoshenii]. Scientific Thought of the Caucasus. 1995, 2: 67-71. (In Russ)

42. Gasanov MR. The Caspian campaign of Peter I 1722-1723 - one of the important stages in the development of Russian-Dagestan relations [Kaspiiskii pokhod Petra I 1722-1723 gg. - odin iz vazhnykh etapov $v$ razvitii russko-dagestanskikh vzaimootnoshenii]. Makhachkala: Epoha, 2015.

43. The history of centuries-old relations and unity of the peoples of Dagestan with Russia. To the 15oth anniversary of the final entry of Dagestan into Russia [Istoriya mnogovekovykh vzaimootnoshenii $i$ edineniya narodov Dagestana $s$ Rossiei. K 15o-letiyu okonchatel'nogo vkhozhdeniya Dagestana $v$ sostav Rossii]. Makhachkala: IHAE DSC RAS, 2009. (In Russ)

44. History of the peoples of Dagestan from ancient times to the present day. Vol. 1 [Istoriya narodov Dagestana s drevneishikh vremen do nashikh dnei]. Moscow: Nauka, 2004. (In Russ)

45. North Caucasus as part of the Russian Empire [Severnyi Kavkaz v sostave Rossiiskoi imperii]. Moscow: New lit. review, 2007. (In Russ)

46. Durov IG. Provisions for the Russian army and navy in the Persian campaign of 1722-1723. Blood. Powder. Laurels: Wars of Russia in the Baroque Era (1700-1762) [Proviantskoe obespechenie russkoi armii i flota $v$ Persidskom pokhode 1722-1723 gg.]. Issue I. St. Petersburg, 2002: 3744. (In Russ)

47. Petrukhintsev NN. Disgraced field marshal [Opal'nyi fel'dmarshal]. Rodina. 1993, 12: 34-37.

48. Petrukhintsev NN. Brugeman's project and the Russian occupation of the Caspian regions in the twenties of the 18th century [Proekt Brugemana i russkaya okkupatsiya prikaspiiskikh oblastei $v$ dvadtsatykh godakh XVIII veka]. Caspian transit. Moscow: Di-Dik Tanais, 1996, 2(5-6): 566-581.

49. Polievktov MA. Access to the sea [Vykhod $k$ moryu]. Caspian transit. Moscow: Di-Dik Tanais, 1996, 2(5-6): 522-548. (In Russ)

50. Baryshnikova N.V. The Caucasian policy of Peter I [Kavkazskaya politika Petra I]: dissertation. Makhachkala, 1999. (In Russ)

51. Kasumov RM. The Caspian campaign of Peter I and Russian-Dagestan relations in the first half of the 18th century [Kaspiiskii pokhod Petra I i russko-dagestanskie otnosheniya $v$ pervoi polovine XVIII v]: dissertation. Makhachkala, 1999. (In Russ) 5о. Барышникова Н.В. Кавказская политика Петра I: дис. ... канд. ист. наук / Барышникова Наталья Вячеславовна. - Махачкала, 1999. - 194 c.

51. Касумов Р.М. Каспийский поход Петра I и русско-дагестанские отношения в первой половине XVIII в.: дис. ... канд. ист. наук / Касумов Рамазан Магомедович. - Махачкала, 1999. - 188 с.

52. Рахаев Д.Я. Политика России на Северном Кавказе в первой четверти XVIII века: автореф. дис. ... канд. ист. наук / Д.Я. Рахаев. - Нальчик, 2008. - 27 с.

53. Саламова Н.А. Кавказ и Причерноморье в русско-турецких отношениях: от Каспийского похода Петра I до присоединения Крыма к России (1722-1783 гг.): автореф. дис. ... канд. ист. наук / Саламова Написат Абдулгамидовна. - Махачкала, 2002. - 29 с.

54. Сотавов Х.Н. Дагестан в кавказской политике России, Ирана и Турции в первой половине XVIII в.: автореф. дис. ... канд. ист. наук / Сотавов Халид Надирпашаевич. - Махачкала, 2002. - 30 с.

55. Чекулаев Н.Д. Российские войска в Дагестане 1722-1735 гг.: Проблемы кавказской политики в регионе: дис. ... канд. ист. наук / Н. Д. Чекулаев. - Махачкала, 2008. - 222 с.

56. Курукин И.В. «...Провинции в полное владение и состояние привести трудно (рапорт М.А. Матюшкина Петру I от 19 января 1725 г.)» / И.В. Курукин // Отечественные записки. - 2005. - № 4. - С. 341-345.

57. Курукин И.В. «Азиатцкой народ» глазами российских генералов: опыт взаимодействия «Персидского корпуса» с населением прикаспийских провинций в 1723-1735 гг. / И.В. Курукин // Астраханские Петровские чтения: «Россия - Астрахань - Восток: интегральное взаимодействие (к 3оо-летию образования Астраханской губернии)» : материалы Международной научной конференции. - Астрахань: Астраханский гос. унив.ерситет, 2018. - C. 187-189.

58. Курукин И.В. Завещание генерал-майора И. Штерншанца 1728 г.: жизнь и смерть офицера экспедиционного «Низового корпуса» в «новоприсоединенных провинциях» Ирана / И.В. Курукин // Вестник архивиста. - 2019. - № 3. - С. 767-777.

59. Курукин И.В. Планы и итоги Персидского похода Петра I // Единорогъ: Матери- 
52. Rakhaev DYa. Russian policy in the North Caucasus in the first quarter of the 18th century [Politika Rossii na Severnom Kavkaze v pervoi chetverti XVIII veka]: dissertation. Nalchik, 2008.

53. Salamova NA. Caucasus and Black Sea region in Russian-Turkish relations: from the Caspian campaign of Peter I to the annexation of the Crimea to Russia (1722-1783) [Kavkaz i Prichernomor'e $v$ russko-turetskikh otnosheniyakh: ot Kaspiiskogo pokhoda Petra I do prisoedineniya Kryma k Rossii (1722-1783 gg.)]: dissertation. Makhachkala, 2002. (In Russ)

54. Sotavov KhN. Dagestan in the Caucasian policy of Russia, Iran and Turkey in the first half of the 18th century [Dagestan $v$ kavkazskoi politike Rossii, Irana i Turtsii $v$ pervoi polovine XVIII v.]: dissertation. Makhachkala, 2002. (In Russ)

55. Chekulaev ND. Russian troops in Dagestan 1722-1735: Problems of Caucasian politics in the region [Rossiiskie voiska $v$ Dagestane 1722-1735 gg.: Problemy kavkazskoi politiki $v$ regione]: dissertation. Makhachkala, 2008. (In Russ)

56. Kurukin IV. «... It is difficult to bring the provinces into full possession and state (report of M.A. Matyushkin to Peter I of January 19, 1725)» [«...Provintsii $\mathrm{v}$ polnoe vladenie i sostoyanie privesti trudno (raport M.A. Matyushkina Petru I ot 19 yanvarya 1725 g.)»]. Otechestvennye zapiski. 2005, 4: 341345. (In Russ)

57. Kurukin IV. The "Asian people» through the eyes of Russian generals: the experience of interaction between the "Persian corps» and the population of the Caspian provinces in 1723-1735 [«Aziattskoi narod» glazami rossiiskikh generalov: opyt vzaimodeistviya «Persidskogo korpusa» S naseleniem prikaspiiskikh provintsii v 1723-1735 gg.]. Astrakhan Petrovsky readings: "Russia - Astrakhan - East: integral interaction (to the 3ooth anniversary of the formation of the Astrakhan province)»: proceedings of the International scientific conference. - Astrakhan: Astrakhan State University, 2018:187-189. (In Russ)

58. Kurukin IV. Testament of Major General I. Sternshants of 1728: life and death of an officer of the expeditionary "Nizovoy Corps» in the «newly annexed provinces» of Iran [Zaveshchanie general-maiora I. Shternshantsa 1728 g.: zhizn' i smert' ofitsera ekspeditsionnogo «Nizovogo korpusa» $v$ «novoprisoedinennykh provintsiyakh» Irana]. Bulletin of the archivist. 2019, 3: 767-777. (In Russ)

59. Kurukin IV. Plans and results of the Persian campaign of Peter I [Plany i itogi Persidskogo pokhoda Petra I] . Unicorn: Materials on the military алы по военной истории Восточной Европы эпохи Средних веков и Раннего Нового времени / И.В. Курукин. - М.: Квадрига, 2011. Вып. 2. - С. 110-128.

6о. Курукин И.В. Управление «новоприсоединенными провинциями» после Персидского похода 1722-1723 годов: Имперские надежды и восточные «обычаи» // Петр I и Восток: материалы XI Международного петровского конгресса / И.В. Курукин. - СПб.: Европ. дом, 2019. - С. 99-104.

61. Курукин И.В. Уроки «персидской глупости»: из истории вопроса о мытье русских сапог в Индийском океане / И.В. Курукин // Родина. - 2001. - № 5. - С. 69-75.

62. Курукин И.В. Персидский поход Петра Великого. Низовой корпус на берегах Каспия (1722-1735) / И.В. Курукин. - М.: Квадрига, 2010. $-381 \mathrm{c}$.

63. Памятники времен утверждения русского владычества на Кавказе: в 2 вып. / под ред. В.А. Потто. - Тифлис: Тип. Штаба Кавказского воен. округа, 1906. Вып. I. - С. 34-37.

64. Абдусаламов М.-П.Б. Аграханское казачье войско в планах Российской империи на Северном Кавказе (1722-1735 гг.) / М.-П. Б. Абдусаламов, Н. Д. Чекулаев // Вопросы истории. - 2019. - № 4. - С. 120-128.

65. Абдусаламов М.-П.Б. Из истории Персидского похода Петра I: битва под Эндиреем 1722 г. / М.-П. Б. Абдусаламов, Н. Д. Чекулаев // Гуманитарные науки в Сибири. - 2015. T. 22. № 4. - C. 36-40.

66. Абдусаламов М.-П.Б. Комплектование гарнизона крепости Святого Креста (1722-1735 гг.) по материалам Центрального государственного архива Республики Дагестан / М.-П.Б. Абдусаламов, Н.Д. Чекулаев // История, археология и этнография Кавказа. - 2020. - T. 16. № 2. - С. 264-279.

67. Абдусаламов М.-П.Б. Военное судопроизводство в Бакинском гарнизоне (17221735 гг.) / М.-П.Б. Абдусаламов, Н.Д. Чекулаев, А.О. Муртазаев // Исторические, философские, политические и юридические науки, культурология и искусствоведение. Вопросы теории и практики. - 2015. - № 1 (51). - C. 13-16.

68. Чекулаев Н.Д. Армянские эскадроны в составе русских войск. 1723-1764 гг. / Н.Д. Чекулаев // Военно-исторический журнал. - 2008. - № 12. - С. 76-77. 
history of Eastern Europe of the Middle Ages and Early Modern times. Moscow: Quadriga. 2011, 2: 110-128. (In Russ)

60. Kurukin IV. Management of the «newly annexed provinces» after the Persian campaign of 1722-1723: Imperial hopes and eastern «customs» [Upravlenie «novoprisoedinennymi provintsiyami» posle Persidskogo pokhoda 1722-1723 godov: Imperskie nadezhdy i vostochnye «obychai»]. Peter I and the East: materials of the XI International Peter's Congress. St. Petersburg: Evrop. dom, 2019: 99-104. (In Russ)

61 Kurukin IV. Lessons from «Persian stupidity»: from the history of the issue of washing Russian boots in the Indian Ocean [Uroki «persidskoi gluposti»: iz istorii voprosa o myt'e russkikh sapog $v$ Indiiskom okeane]. Rodina. 2001, 5: 69-75.

62. Kurukin IV. The Persian campaign of Peter the Great. Lower corps on the shores of the Caspian Sea (1722-1735) [Persidskii pokhod Petra Velikogo. Nizovoi korpus na beregakh Kaspiya (1722-1735)]. Moscow: Quadriga, 2010. (In Russ)

63. Potto V.A. (ed.) Monuments from the time of the establishment of Russian rule in the Caucasus: in 2 issues [Pamyatniki vremen utverzhdeniya russkogo vladychestva na Kavkaze: $v 2$ vyp.]. Tiflis: Type. Headquarters of the Caucasian military. District, 1906. 1: 34-37. (In Russ)

64. Abdusalamov M.-P.B. Agrakhan Cossack army in the plans of the Russian Empire in the North Caucasus (1722-1735) [Agrakhanskoe kazach'e voisko $v$ planakh Rossiiskoi imperii na Severnom Kavkaze (1722-1735 gg.)]. Questions of history. 2019, 4: 120-128. (In Russ)

65 Abdusalamov M-PB. From the history of the Persian campaign of Peter I: the battle of Endirei in 1722 [Iz istorii Persidskogo pokhoda Petra I: bitva pod Endireem $1722 \mathrm{~g}$.]. Gumanitarnie nauki $v \mathrm{Si}$ biri. 2015, 22(4): 36-40. (In Russ)

66. Abdusalamov M-PB. Garrison recruitment of the fortress of the Holy Cross (1722-1735): on the materials of the central state archive of the Republic of Dagestan [Komplektovanie garnizona kreposti Svyatogo Kresta (1722-1735 gg.) po materialam Tsentral'nogo gosudarstvennogo arkhiva Respubliki Dagestan]. History, archeology and ethnography of the Caucasus. 2020, 16(2): 264-279. (In Russ)

67. Abdusalamov M.-P.B. Military legal proceedings in the Baku garrison (1722-1735). Historical, philosophical, political and legal sciences, cultural studies and art history. Questions of theory and practice [Voennoe sudoproizvodstvo $v$ Bakinskom garnizone (1722-1735 gg.) / M.-P. B. Abdusalamov,
69. Чекулаев Н.Д. Военный суд в крепости Святого Креста / Н.Д. Чекулаев // Вестник Института истории, археологии и этнографии. - 2005. - № 1. - С. 105-109.

70. Чекулаев Н.Д. Генерал-аншеф В. Я. Левашов как российский правитель на Кавказе (1722-1735 гг.) / Н.Д. Чекулаев // Всероссийские Миллеровские чтения. - 2016. - № 5. C. $116-124$.

71. Чекулаев Н.Д. Разрыв шамхала Адиль-Гирея с русскими властями, его причины и последствия / Н.Д. Чекулаев // Вестник Института истории, археологии и этнографии. - 2006. - № 1 (5). - С. 26-36.

72. Чекулаев Н.Д. Расположение войск гарнизона крепости Святого Креста на Кавказе. 1722-1735 гт. / Н.Д. Чекулаев // Военно-исторический журнал. - 2007. - № 7. - С. 36-39.

73. Чекулаев Н.Д. Российские войска в Дагестане в контексте кавказской политики России (1722-1735 гг.) / Н.Д. Чекулаев. - Махачкала: ИИАЭ ДНЦ РАН, 2008. - 208 с.

74. Абдусаламов М.-П.Б. Выступление шамхала Адиль-Гирея в 1725 г. против российского военного присутствия в Дагестане и начало Кавказской войны / М.-П.Б. Абдусаламов, Н.Д. Чекулаев // Вестник КрасГАУ. - 2013. - № 12 (87). - C. 272-280.

75. Иноземцева Е.И. «Шелковый транзит» из Персии через Дагестан и Россию в Европу - важный фактор развития российского судоходства на Каспии XVIII в. / И.Е. Иноземцева // Вестник Дагестанского научного центра. 2011. - № 42. - C. 69-73.

76. Иноземцева Е.И. Дагестанский вектор кавказской политики Петра I / И.Е. Иноземцева // Кавказ и Ближний Восток: от Каспийского похода Петра I до распада державы Надир-шаха: материалы Международной научной конференции, проведенной в рамках «Года Российской истории». - Махачкала: Алеф, 2012. - С. 121-126.

77. Иноземцева Е.И. Казачество России в контексте крупномасштабной внешнеполитической акции Низового корпуса императорских войск в Юго-Западном Прикаспии (1722-1735 гг.) / И.Е. Иноземцева // Вестник Института истории, археологии и этнографии. - 2016. - № 2. (46). - С. 13-19.

78. Иноземцева Е.И. Кавказское направление во внешней торгово-экономической политике Петра I / И.Е. Иноземцева // «И Божья благодать сошла...»: Романовы и 
N. D. Chekulaev, A. O. Murtazaev // Istoricheskie, filosofskie, politicheskie i yuridicheskie nauki, kul'turologiya $i$ iskusstvovedenie. Voprosy teorii $i$ praktiki]. 2015, 1 (51): 13-16. (In Russ)

68. Chekulaev ND. Armenian squadrons as part of the Russian troops. 1723-1764 [Armyanskie eskadrony $v$ sostave russkikh voisk. 1723-1764 gg.]. Voenno-istoricheski zhurnal. 2008, 12: 76-77.

69. Chekulaev ND. Military court in the fortress of the Holy Cross [Voennyi sud v kreposti Svyatogo Kresta]. Bulletin of the Institute of History, Archeology and Ethnography. 2005, 1: 105-109.

70. Chekulaev ND. General-in-chief V. Ya. Levashov as a Russian ruler in the Caucasus (17221735) [General-anshef V. Ya. Levashov kak rossiiskii pravitel' na Kavkaze (1722-1735 gg.)]. All-Russian Millerov readings. 2016, 5: 116-124.

71. Chekulaev ND. The rupture of Shamkhal Adil-Girei with the Russian authorities, its causes and consequences [Razryv shamkhala Adil'Gireya s russkimi vlastyami, ego prichiny i posledstviya]. Bulletin of the Institute of History, Archeology and Ethnography. 2006, 1(5): 26-36.

72. Chekulaev ND. The disposition of the troops of the garrison of the fortress of the Holy Cross in the Caucasus. 1722-1735 [Raspolozhenie voisk garnizona kreposti Svyatogo Kresta na Kavkaze. 1722-1735 gg.]. Voenno-istoricheski zhurnal. 2007, 7: 36-39. (In Russ)

73. Chekulaev N.D. Russian troops in Dagestan in the context of the Caucasian policy of Russia (1722-1735) [Rossiiskie voiska v Dagestane v kontekste kavkazskoi politiki Rossii (1722-1735 gg.)]. Makhachkala: IHAE DSC RAN, 2008. (In Russ)

74. Abdusalamov M-PB. Speech by Shamkhal Adil-Girey in 1725 against the Russian military presence in Dagestan and the beginning of the Caucasian War [Vystuplenie shamkhala Adil'-Gireyav 1725 g. protiv rossiiskogo voennogo prisutstviya $v$ Dagestane i nachalo Kavkazskoi voiny]. Bulletin of KrasGAU. 2013, 12(87): 272-280. (In Russ)

75. Inozemtseva IE. «Silk transit» from Persia through Dagestan and Russia to Europe is an important factor in the development of Russian shipping in the Caspian in the 18th century [ «Shelkovyi tranzit» iz Persii cherez Dagestan i Rossiyu v Evropu - vazhnyi faktor razvitiya rossiiskogo sudokhodstva na Kaspii XVIII v.]. Bulletin of the Dagestan Scientific Center. 2011, 42: 69-73. (In Russ)

76. Inozemtseva IE. Dagestan vector of the Caucasian policy of Peter I. Caucasus and the Middle East: from the Caspian campaign of Peter I to the collapse of the state of Nadir Shah: proceedings of the International scientific conference held with-
Северный Кавказ: материалы IV Международных дворянский чтений. - Краснодар: Изд-во «Кубанькино», 2008. - С. 3-10.

79. Иноземцева Е.И. Дербентская таможня в контексте кавказской экономической политики России (1722-1735 гг.) / И.Е. Иноземцева, Н.Д. Чекулаев // Современные проблемы науки и образования. - 2013. - № 6. С. $810-814$.

8о. Иноземцева Е.И. О союзниках России в Западном Прикаспии в 1722-1735 годах / И.Е. Иноземцева // Петр I и Восток: материалы XI Международного петровского конгресса. - СПб.: Европ. дом, 2019. - С. 88-98.

81. Тепкеев B.T. Документы по истории калмыцко-дагестанских отношений в период Персидского похода 1722-1723 гг. (по материалам Национального архива Республики Калмыкия) / В.Т. Тепкеев // Бюллетень Калмыцкого научного центра РАН. - 2017. - № 1. - C. 6-14.

82. Тепкеев В.T. Участие калмыков в Дербентском походе 1722 г. / В.Т. Тепкеев // Новый исторический вестник. - 2017. - № 3 (53). - C. 15-22.

83. Гарунова Н.Н. Российские города-крепости в контексте политики России на Северо-Восточном Кавказе в XVIII - в первой половине XIX в.: проблемы политической, экономической и культурной интеграции / Н.Н. Гарунова. - Махачкала: Тип. «Радуга-1», 2007. - $275 \mathrm{c}$.

84. Гарунова Н.Н. Терский город и крепость Святого Креста - опорные пункты кавказской политики России в XVI - в первой половине XVIII в. // Памятники фортификации: история, реставрация, использование / Н.Н. Гарунова. - Архангельск: Архангельский краеведческий музей, 2012. - С. 218225.

85. Гарунова Н.Н. Кавказский этап в биографии генерала В.Я. Левашова (17221735 гг.) / Н.Н. Гарунова // Вестник Дагестанского государственного университета. Серия 2. Гуманитарные науки. - 2016. - Т. 31. № 3.C. $12-16$.

86. Сотавов Н.А. Кавказские походы Петра I и Надир-шаха Афшара и их последствия для народов региона / Н.А. Сотавов // Кавказ и Ближний Восток: от Каспийского похода Петра I до распада державы Надир-шаха : материалы Международной научной 
in the framework of the Year of Russian History [Dagestanskii vektor kavkazskoi politiki Petra I / I. E. Inozemtseva // Kavkaz i Blizhnii Vostok: ot Kaspiiskogo pokhoda Petra I do raspada derzhavy Nadir-shakha: materialy Mezhdunarodnoi nauchnoi konferentsii, provedennoi $v$ ramkakh «Goda Rossiiskoi istorii».]. Makhachkala: Alef, 2012:121-126. (In Russ)

77. Inozemtseva IE. The Cossacks of Russia in the context of a large-scale foreign policy action of the Lower Corps of the Imperial Forces in the South-Western Caspian Region (1722-1735) [ Kazachestvo Rossii $v$ kontekste krupnomasshtabnoi vneshnepoliticheskoi aktsii Nizovogo korpusa imperatorskikh voisk $v$ Yugo-Zapadnom Prikaspii (1722-1735 gg.)]. Bulletin of the Institute of History, Archeology and Ethnography. 2016, 2(46): 13-19. (In Russ)

78. Inozemtseva IE. Caucasian direction in foreign trade and economic policy of Peter I. "And God's grace descended ...»: The Romanovs and the North Caucasus: materials of the IV International noble readings [Kavkazskoe napravlenie vo vneshnei torgovo-ekonomicheskoi politike Petra I]. Krasnodar: Kubankino Publ., 2008:3-10.

79. Inozemtseva IE. Derbent customs in the context of the Caucasian economic policy of Russia (1722-1735) [Derbentskaya tamozhnya $v$ kontekste kavkazskoi ekonomicheskoi politiki Rossii (1722-1735 gg.)]. Modern problems of science and education. 2013, 6: 810-814. (In Russ)

8o. Inozemtseva IE. On Russia's allies in the Western Caspian region in 1722-1735 [O soyuznikakh Rossii v Zapadnom Prikaspii v 1722-1735 godakh]. Peter I and the East: proceedings of the XI International Peter's Congress. St. Petersburg, 2019. p. 88-98. (In Russ)

81. Tepkeev VT. Documents on the history of Kalmyk-Dagestan relations during the Persian campaign of 1722-1723 (based on the materials of the National Archives of the Republic of Kalmykia) [Dokumenty po istorii kalmytsko-dagestanskikh otnoshenii $v$ period Persidskogo pokhoda 17221723 gg. (po materialam Natsional'nogo arkhiva Respubliki Kalmykiya)]. Journal of the Kalmyk Scientific Center of the Russian Academy of Sciences. 2017, 1: 6-14. (In Russ)

82. Tepkeev VT. Participation of Kalmyks in the Derbent campaign of 1722 [Uchastie kalmykov $v$ Derbentskom pokhode $1722 \mathrm{~g}$. / V. T. Tepkeev]. New historical bulletin. 2017, 3(53): 15-22.

83. Garunova NN. Russian fortress cities in the context of Russia's policy in the North-Eastern конференции, проведенной в рамках «Года Российской истории». - Махачкала: Алеф, 2012. - C. 233-240.

87. Магомеддадаев А.М. Азово-Каспийские походы Петра I в контексте международной политики и нашествия Надир-шаха на Кавказ / А.М. Магомеддадаев, 3.М. Амирова // Кавказ и Ближний Восток: от Каспийского похода Петра I до распада державы Надир-шаха : материалы Международной научной конференции, проведенной в рамках «Года Российской истории». Махачкала: Алеф, 2012. - С. 157-174.

88. Гапуров Ш.А. Каспийский поход Петра I в оценках зарубежных историков / Ш.А. Гапуров // Кавказ и Ближний Восток: от Каспийского похода Петра I до распада державы Надир-шаха: материалы Международной научной конференции, проведенной в рамках «Года Российской истории». - Махачкала: Алеф, 2012. - С. 66-74.

89. Аваков П.А. Персидский поход Петра I и донское казачество / П.А. Аваков // Петр I и Восток: материалы XI Международного петровского конгресса. - СПб.: Европ. дом, 2019. - C. $28-45$.

90. Гаджиев М.С. Дербентский гарнизон Низового корпуса Русской Императорской армии (1722-1735): Краткий обзор / М.С. Гаджиев, Е.И. Иноземцева, Н.Д. Чекулаев // Петр I и Восток : материалы XI Международного петровского конгресса. - СПб. : Европ. дом, 2019. - С. 72-87.

91. Сперанская Н.М. Дневник Персидского похода 1722-1723 годов из Библиотеки Вольтера / Н.M. Сперанский // Петр I и Восток: материалы XI Международного петровского конгресса. - СПб.: Европ. дом, 2019. - С. 164184.

92. Лаптева Т.A. Дербент в составе Российском империи: Письма коменданта полковника А.Т. Юнгера в Кабинет Е.И.В. (1722-1725) / Т.А. Лаптева // Петр I и Восток: материалы XI Международного петровского конгресса. - СПб.: Европ. дом, 2019. - С. 105-129.

93. Гаджиев М.С. Петр Великий и Дербент / М.С. Гаджиев // Петровские памятники России и Европы: изучение, сохранение, культурный туризм: материалы VII Международного Петровского конгресса. 2016. - С. 232-244. 
Caucasus in the 18th - the first half of the 19th century: problems of political, economic and cultural integration [Rossiiskie goroda-kreposti $v$ kontekste politiki Rossii na Severo-Vostochnom Kavkaze v XVIII - v pervoi polovine XIXv.: problemy politicheskoi, ekonomicheskoi i kul'turnoi integratsii]. Makhachkala: Raduga-1, 2007.

84. Garunova NN. The Tersk city and the fortress of the Holy Cross were the strongholds of the Caucasian policy of Russia in the 16th - the first half of the 18th century [Terskii gorod i krepost' Svyatogo Kresta - opornye punkty kavkazskoi politiki Rossii $v$ XVI - v pervoi polovine XVIII $v$. // Pamyatniki fortifikatsii: istoriya, restavratsiya, ispol'zovanie]. Monuments of fortification: history, restoration, use. Arkhangelsk: Arkhangelsk Museum of Local Lore, 2012. p. 218-225.

85. Garunova NN. The Caucasian stage in the biography of General V.Ya. Levashova (1722-1735) [Kavkazskii etap $v$ biografii generala V.Ya. Levashova (1722-1735 gg.)]. Bulletin of the Dagestan State University. Series 2. Humanities. 2016, 31(3): 12-16. (In Russ)

86. Sotavov NA. The Caucasian campaigns of Peter I and Nadir Shah Afshar and their consequences for the peoples of the region [Kavkazskie pokhody Petra I $i$ Nadir-shakha Afshara i ikh posledstviya dlya narodov regiona]. Caucasus and the Middle East: from the Caspian campaign of Peter I to the collapse of the state of Nadir Shah: materials of the International scientific conference held within the framework of the "Year Russian history». Makhachkala: Alef, 2012: 233-240.

87. Magomeddadaev AM. Azov-Caspian campaigns of Peter I in the context of international politics and the invasion of Nadir Shah in the Caucasus [Azovo-Kaspiiskie pokhody Petra I v kontekste mezhdunarodnoi politiki i nashestviya Nadir-shakha na Kavkaz]. Caucasus and the Middle East: from the Caspian campaign of Peter I to the collapse of the state of Nadir Shah: materials International scientific conference held within the framework of the "Year of Russian History". Makhachkala: Alef, 2012:157-174. (In Russ)

88. Gapurov ShA. The Caspian campaign of Peter I in the assessments of foreign historians [Kaspiiskii pokhod Petra I v otsenkakh zarubezhnykh istorikov]. Caucasus and the Middle East: from the Caspian campaign of Peter I to the collapse of the state of Nadir Shah: materials of the International scientific conference, conducted in the framework of the "Year of Russian History». Makhachkala: Alef, 2012:66-74. (In Russ)
94. Кидирниязов Д.С. Дагестан в системе международных отношений (XVIII - конец 20-Х гг. XIX в.) / Д. С. Кидирниязов. - М. : Парнас, 2011. - 456 с.

95. Кидирниязов Д.С. Дагестан и Северный Кавказ в политике России в XVIII - 20-х гг. XIX в. / Д.С. Кидирниязов. - Махачкала : Алеф, ИП Овчинников М.А., 2013. - 456 с.

96. Магомедов Н.A. Международные отношения на Северо-Восточном Кавказке в XVIII - в первой трети XIX в. / Н.А. Магомедов. Махачкала: Алеф, 2019. - 228 с.

97. Магарамов Ш.А. Российско-дагестанские дипломатические отношения накануне Каспийского похода Петра I / Ш.А. Магарамов // Российская история. - 2017. - № 1. - С. 56-61.

98. Оруджев Ф.Н. Влияние Каспийского похода Петра Великого на пророссийскую ориентацию дагестанской политической элиты / Ф.Н. Оруджев // Исторические, философские, политические и юридические науки, культурология и искусствоведение. Вопросы теории и практики. - 2015. - № 7 (57). Ч. I. - C. 112-114.

99. Западный Прикаспий в составе Российской империи (1722-1735 гг.): сборник архивных документов / Сост. Е.И. Иноземцева, Ш.А. Магарамов, Н.Д. Чекулаев. - Махачкала: МавраевЂ, 2020. - 376 с.

100. Магарамов Ш.А. Финансово-хозяйственная деятельность Дербентского гарнизона (1725-1726 гг.) / Ш.А. Магарамов, Н.Д. Чекулаев // Вопросы истории. - 2020. - № 5. - С. 202-207.

101. Магарамов Ш.А. Доходы российской казны на материалах Дербентского гарнизона Низового корпуса / Ш.А. Магарамов, Е.И. Иноземцева, Н.Д. Чекулаев // Вестник Волгоградского государственного университета. Сер. 4. История. Регионоведение. Международные отношения. - 2021. - Т. 26. № 1. - C. $157-171$.

102. Магарамов Ш.А. Несбывшиеся планы Петра Великого: дербентский порт и купеческий город в устье Куры / Ш.А. Магарамов // Объекты культурного наследия Петровской эпохи на юге России: проблемы изучения, сохранения и музеефикации: сборник материалов конференции. - Волгоград: Сфера, 2020. - C. $108-116$. 
89. Avakov PA. The Persian campaign of Peter I and the Don Cossacks [Persidskii pokhod Petra I $i$ donskoe kazachestvo / P. A. Avakov]. Peter I and the East: Proceedings of the XI International Peter's Congress. St. Petersburg: Evrop. house, 2019: 28-45. (In Russ)

90. Gadzhiev MP. Derbent garrison of the Lower Corps of the Russian Imperial Army (17221735): A brief overview [Derbentskii garnizon Nizovogo korpusa Russkoi Imperatorskoi armii (1722-1735): Kratkii obzor]. Peter I and the East: Proceedings of the XI International Peter's Congress. St. Petersburg: Europ. house, 2019:72-87. (In Russ)

91. Speranskaya NM. Journal of the Persian campaign of 1722-1723 from the Voltaire Library [Dnevnik Persidskogo pokhoda 1722-1723 godov iz Biblioteki Vol'tera]. Peter I and the East: proceedings of the XI International Peter's Congress. St. Petersburg: Evrop. house, 2019:164-184.

92. Lapteva TA. Derbent as part of the Russian Empire: Letters from the commandant of Colonel A. T. Yunger to the Cabinet of E.I.V. (1722-1725) [Derbent $v$ sostave Rossiiskom imperii: Pis'ma komendanta polkovnika A. T. Yungera $v$ Kabinet E.I.V. (1722-1725)]. Peter I and the East: materials of the XI International Peter's Congress. St. Petersburg: Evrop. house, 2019:105-129. (In Russ)

93. Gadzhiev MP. Peter the Great and Derbent [Petr Velikii $i$ Derbent]. Peter's Monuments of Russia and Europe: Study, Preservation, Cultural Tourism: Proceedings of the VII International Peter's Congress. 2016:232-244. (In Russ)

94. Kidirniyazov DP. Dagestan in the system of international relations (XVIII - late 20s. XIX century) [Dagestan $v$ sisteme mezhdunarodnykh otnoshenii (XVIII - konets 2O-kh gg. XIX v.)]. Moscow: Parnas, 2011. (In Russ)

95. Kidirniyazov DP. Dagestan and the North Caucasus in Russian politics in the 18-20s. XIX century [Dagestan i Severnyi Kavkaz v politike Rossii v XVIII - 2O-kh gg. XIX v.]. Makhachkala: Alef, 2013. (In Russ)

96. Magomedov NA. International relations in the North-East Caucasus in the XVIII - in the first third of the XIX century [Mezhdunarodnye otnosheniya na Severo-Vostochnom Kavkaze $v$ XVIII - v pervoi treti XIX v.]. Makhachkala: Alef, 2019.

97. Magaramov ShA. Russian-Dagestan diplomatic relations on the eve of the Caspian campaign of Peter I [Rossiisko-dagestanskie diplomaticheskie otnosheniya nakanune Kaspiiskogo pokhoda
103. Полчаева Ф.А. Образ Петра I в исторической памяти населения Дагестана / Ф.А. Полчаева, Д. А. Касымов // История, археология и этнография Кавказа. - 2020. T. 16. № 4. - C. 888-899. 
Petra I]. Russian history. 2017, 1: 56-61. (In Russ)

98. Orudzhev FN. Influence of the Caspian campaign of Peter the Great on the pro-Russian orientation of the Dagestan political elite. Historical, philosophical, political and legal sciences, cultural studies and art history [Vliyanie Kaspiiskogo pokhoda Petra Velikogo na prorossiiskuyu orientatsiyu dagestanskoi politicheskoi elity / F. N. Orudzhev]. Questions of theory and practice. 2015, 7(57): 112-114.(In Russ)

99. Western Caspian Sea within the Russian Empire (1722-1735): a collection of archival documents [Zapadnyi Prikaspii $v$ sostave Rossiiskoi imperii (1722-1735 gg.): sbornik arkhivnykh dokumentov]. Makhachkala: Mavraev, 2020.(In Russ)

100. Magaramov ShA. Financial and economic activities of the Derbent garrison (1725-1726) [Finansovo-khozyaistvennaya deyatel'nost' Derbentskogo garnizona (1725-1726 gg.)]. Questions of history. 2020, 5: 202-207.(In Russ)

101. Magaramov ShA. Incomes of the Russian treasury on the materials of the Derbent garrison of the Nizovoy Corps [Dokhody rossiiskoi kazny na materialakh Derbentskogo garnizona Nizovogo korpusa]. Bulletin of the Volgograd State University. Ser. 4. History. Regional studies. International relationships. 2021, 26(1): 157-171. (In Russ)

102. Magaramov ShA. Unfulfilled plans of Peter the Great: the port of Derbent and the merchant city at the mouth of the Kura [Nesbyvshiesya plany Petra Velikogo: derbentskii port $i$ kupecheskii gorod $v$ ust'e Kury]. Objects of the cultural heritage of Peter the Great in southern Russia: problems of study, preservation and museification: collection of conference materials. Volgograd: Sfera, 2020:108-116. (In Russ)

103. Polchaeva FA. The image of Peter I in the historical memory of the population of Dagestan [Obraz Petra I v istoricheskoi pamyati naseleniya Dagestana]. History, archeology and ethnography of the Caucasus. 2020, 16(4): 888-899. 